\title{
ACCOUNTING EDUCATION \\ IN AN OPEN DISTANCE LEARNING ENVIRONMENT: CASE STUDIES FOR PERVASIVE SKILLS ENHANCEMENT
}

\author{
Yolande REYNEKE \\ Department of Management Accounting \\ University of South Africa \\ Pretoria, South Africa \\ Christina Cornelia SHUTTLEWORTH \\ College of Accounting Sciences \\ University of South Africa \\ Pretoria, South Africa
}

\begin{abstract}
Distance learning institutions allow access to many students who do not enjoy the luxury of studying fulltime at contact-based universities by providing flexibility in terms of time, space and finances. Globally, accountants are vital for the economy and it is important that higher education institutions empower them with the necessary skills to face the volatile working environment. Equipping accounting students with only discipline-specific knowledge, does not result in practice-ready accountants, which cause great concern for professional accounting bodies as well as employers. Pervasive skills are soft skills, also sometimes referred to as personal attributes allowing effective interaction between people. Using case studies to develop pervasive skills in accounting education, specifically in Open Distance Learning (ODL) institutions, is regarded as a fairly unexplored area. A qualitative research approach was followed whereby interviews were conducted with management members of the College of Accounting Sciences (CAS) at the University of South Africa (UNISA). The interviews provided insight into how ODL accounting educators in a developing country perceived the need to introduce a case study-based module to develop pervasive skills. It is recommended that the training of distance education accounting students should be adapted to include case studies for pervasive skills development.
\end{abstract}

Keywords: Distance learning, accounting education, case studies.

\section{INTRODUCTION}

Globally, there is a tremendous need for distance education because individuals with time, geographical and financial constraints, are provided with equal education opportunities. Distance education students usually have fast and easy access to their study material, anywhere, anytime allowing them to retain their jobs and simultaneously save on various education-related costs such as transportation, accommodation and catering (Sad, Goktas, \& Bayrak, 2014). Especially in the accounting field, there is increased pressure on distance education institutions to deliver enough students with all the necessary skills to match market expectations. Tucker (2014) explains that students must be equipped to live in a "multifaceted, multitasking, technology-driven world" and "regardless of their economic background, we must also ensure that all students have equal access to this new technological world".

In recent years, numerous changes in the workplace have increased the demands placed on accountants. These changes include the rapidly changing business environment, globalization, new legislation, continuous improvements in information technology (IT) and the economic 
meltdown. Consequently employers are now looking for accounting graduates with a diverse set of skills and attributes to cope with these demands (Albrecht \& Sack, 2000; De Lange, Jackling, \& Gut, 2006; Gammie, Gammie, \& Cargill, 2002; Hassall \& Milne, 2004; Howieson, 2003; Tucker, 2014; Wessels, 2008). Therefore, tertiary institutions are called upon to deliver well-rounded graduates (Cullen, Richardson, \& O'Brien, 2004; Mohamed \& Lashine, 2003; Tucker, 2014; Van Romburgh \& Van der Merwe, 2015; Wolcott, Baril, Cunningham, Fordham, \& St Pierre, 2002; Boyce, Williams, Kelly, \& Yee, 2001). Meeting the demands of employers and professional bodies, accounting graduates require, in addition to discipline-specific skills, a range of other skills, hereafter referred to as pervasive skills (Arquero Montano, Cardoso, \& Joyce, 2004; De Lange et al., 2006; Gammie et al., 2002; Palmer, Ziegenfuss, \& Pinsker, 2004). In their article, Strauss-Keevy and Mare (2015) refer to pervasive skills as inter alia "employability skills, behavioral skills and interpersonal skills". For purposes of this article, pervasive skills also include other skills such as higher-order skills (Wilton, 2008; CIMA, 2012) and soft skills (Barac, 2009; De Villiers, 2010).

Subsequent to the publishing of the Bedford Committee Report (AAA, 1986), numerous calls to improve accounting students' pervasive skills, in particular their critical thinking, echoed in the literature (Boyce, 2004; Wolcott et al., 2002; Siegel \& Sorenson, 1999; Stout, 1996; Kimmel, 1995). Conventional accounting pedagogy, emphasizing discipline-specific development, leave little scope for the inclusion of pervasive skills in the curriculum. Penn, Currie, Hoad and $O^{\prime} B$ rien (2016), proclaim that various invaluable skills, such as communication, leadership, and team-related skills can be developed by teaching with case studies. Therefore, introducing case studies could achieve a closer alignment between accounting education and accounting practice (Cullen et al., 2004).

In order to bridge this skills gap the Chartered Institute of Management Accountants (CIMA), has for instance, endeavored to help students develop both their discipline specific knowledge as well as their professional capacity by incorporating a case study-based final examination in their new curriculum, effective from January 2015 (CIMA, 2014). This examination assesses the students' ability to demonstrate higher-level skills, for instance synthesis, analysis and evaluation, and skills in effectively presenting and communicating information to users in a way that promotes professionalism (CIMA, 2012). In 2012, the South African Institute of Chartered Accountants (SAICA) also published their intention to implement a multidisciplinary case study-based final examination for trainee accountants eligible to become qualified Chartered Accountants (CAs) (SAICA, 2013). Subsequently, SAICA introduced their Assessment of Professional Competence (APC) examination in November 2014. The case study-based examination allows SAICA to increasingly assess professional and pervasive skills (Oliver, 2012).

Although the use of real-world case study material has become a standard teaching method in many disciplines, for instance business, law and medicine (Penn et al., 2016), limited empirical research has been conducted to support the perceived usefulness of case studies for teaching pervasive skills (Boyce, 2004; Weil, Oyelere, Yeoh, \& Firer, 2001; Wolcott et al., 2002). In order to approach reform in accounting education, it is imperative to gain an understanding of the environment in which students reside (Morris, Burnett, Skousen, \& Akaaboune, 2015). For instance, an open distance learning (ODL) environment differs from a residential, classroom-based environment. Therefore, the objective of this article is to specifically explore whether accounting educators at an ODL institution perceive that there is a need to introduce a case study-based module to prepare accounting students for the professional bodies' case study examinations. The article further endeavors to determine if accounting educators are of the opinion that a case study module would improve ODL students' pervasive skills.

In the remainder of the article, the prior literature concerning the pervasive skills gap and the teaching of pervasive skills in an ODL environment in accounting education is firstly reviewed. Thereafter, a discussion of the research method is presented, followed by the limitations of the study. After the analysis section, conclusions are finally drawn and recommendations are made. 


\section{LITERATURE REVIEW}

A survey conducted among accounting graduates from three Australian universities and Australian practitioners suggested that extensive training was needed before accounting graduates were regarded as having an innate work-ready capacity (Kavanagh \& Drennan, 2008). Professional accounting bodies and employers of accounting graduates have called for accounting education to bridge the identified skills gap by attending to the supposed skills shortages (Ballantine \& McCourt Larres, 2004; Bui \& Porter, 2010; Hassal, Joyce, Arquero Montano, \& Donoso Anes, 2005).

In a study among accounting academics involved in SAICA-accredited academic programmes, Keevy (2013) found that despite a supposed obligation to teach pervasive skills, academics do not perceive themselves as best suited to equip graduates with the required pervasive skills competencies. However, educational institutions have a critical responsibility in delivering practice-ready accounting graduates who are knowledgeable, ethical, responsible and financially literate. Enhancing pervasive skills through formal education is therefore no longer voluntary (Shuttleworth, 2012). The gap between accounting education and the work place is expanding (Rebele \& St. Pierre, 2015) and current literature does not reflect how to best prepare students for the work place.

The debate on whether universities adequately prepare students for the work place is ongoing and it should be emphasized that "universities cannot be all things to all people" (Howieson, Hancock, Segal, Kavanagh, Tempone \& Kent, 2014). Many authors contend that the adopted accounting pedagogies should move away from students' passive mastering of content knowledge, to a more student-centered approach, where they play an active role in their own learning process (Morris et al., 2015; Chu \& Libby, 2010). That being said, a survey of accounting programs in the New York City metropolitan area conducted by DillerHaas (2004) found that the majority $(\mathbf{7 1 \%})$ of programs still used a traditional curriculum, focusing on memorization and the mechanics of recording transactions. Some authors (Woronoff, 2009; Albrecht and Sack, 2000) are of the opinion that universities mostly only focus on discipline-specific competencies, instead of pervasive skills as well. Cooper, Everett and Neu (2005) support this view, stating that there is too much emphasis on repetitive learning of discipline-specific material with a lack of attention to broader educational issues. Boyce, Williams, Kelly and Yee (2001) argue that the accounting profession has a predilection for discipline-specific development of their students and seems to be less interested in pervasive skills development.

However, the literature has examples of researchers who do not believe that educators are solely responsible for pervasive skills development. Gammie et al (2002) are of the opinion that employers' demands for education institutions to equip students with the necessary pervasive skills should not be blindly accepted. They argue that employers are also accountable and should include pervasive skills development in their training programs (Gammie et al., 2002). Donovan (2005) suggests collaboration between universities and the accounting profession in pervasive skills development, and argues that the profession can provide a real-world environment for learning. Howieson et al. (2014) suggest that awareness should be raised among employers regarding limitations within university programs to develop students' pervasive skills and that employers should endeavor to advance learning opportunities within the working environment.

The ability of higher education to develop practice-ready graduates is therefore a contentious matter (Cranmer, 2006; Wilton, 2008). In a study conducted by Bui and Porter (2010) employers signaled that university courses provide students with a conceptual understanding of business, but they also indicated that "real" business knowledge can only be acquired by on-the-job experience. The studies conducted by Cranmer (2006) and Lucas, Cox, Croudace and Mildford (2004) support this finding, as they conclude that it is unrealistic for universities to claim that they can teach the pervasive skills required by practice. 
Institutional constraints are often the reason why accounting education cannot always deliver accounting graduates with the pervasive skills required by employers (Bui \& Porter, 2010). At an ODL institution, such as the University of South Africa (Unisa), student numbers are large when compared to residential universities (Ryan, 2008). Unisa has to cater for students from different generations, namely adults and school leavers, who have different views, knowledge levels, experience levels and expectations (Heydenrych \& Prinsloo, 2010). There is limited face-to-face contact with students (Martin, 2007) and group discussion classes usually happen on an ad-hoc basis once per semester with large numbers of students attending these classes. Consequently, it is perceived as highly unlikely that distance-education lecturers would be able to fit pervasive skills training into the limited available face-to-face time. In addition, the workload of academics has increased (Bezuidenhout, 2013) and they experience time constraints, work constraints and the burden of continuously updating the curriculum.

The borders between distance learning and residential institutions are "becoming increasingly blurred due to the use of technologies" (Heydenrych \& Prinsloo, 2010). Distance education consists of multiple dimensions aiming to overcome any form of distance between students and the institution, educators, study material and fellowstudents (Kamanja, 2007; Mbatha, 2015). Although ODL offers flexibility by minimizing limitations on study in terms of time, access, place, pace of education and method of study (Dzakiria, 2012; Vakoufari, Christina \& Mavroidis, 2014), students face other distinct challenges.

ODL students often experience challenges such as time management, coping with personal stress, deficient IT skills and lack of proficiency in English as instructional language (Geduld, 2013). Geduld (2013) goes so far as to say that critical thinking, organizational and emotional skills are a prerequisite for success in an ODL environment. In addition, lecturers need to consider the demographics of the generation of learners in their classes (Fouche, 2013). Unisa's student profile is diverse in terms of income (ranging from highincome earners to poor students who do not even have electricity at home), age, educational background and working experience (Dzakiria, 2012; Ryan, 2008). Many of the students who study part-time experience a time management problem because they are also employed on a full-time basis. In ODL many learners are faced with the expectation that they already have independent learning skills and the capacity to "engage in activities that require self-direction and self-management of learning" (McLoughlin \& Marshall, 2000). Although it is assumed that learners operating in the 21st century should already have these attributes, this generalization is not applicable to all ODL learners (Dzakiria, 2012).

Despite these many unique challenges in the ODL environment, there are also opportunities to develop accounting students' pervasive skills. For instance, writing skills are improved when students attempt their compulsory written assignments and examinations and also when they e-mail their lecturers. There is an increasing shift to online learning, and this will potentially enhance students' IT skills (Nti, 2015; Kamanja, 2007). Video and satellite conferencing as well as Skype technologies can be utilised for case study discussions in a distance learning environment (Kashora, Van der Poll, \& Van der Poll, 2016). Distance learners have been found by some researchers to be more positive about lifelong learning opportunities than face-to-face students (Sad, Goktas, \& Bayrak, 2014). The use of distance education materials in a traditional accounting course revealed a positive effect on student success (Bozok, 2011).

As far back as 1986, the use of case studies in accounting has been regarded as one of the best methods for developing pervasive skills (AAA, 1986). A study conducted by Ballentine and McCourt Larres (2004) among 84 final-year undergraduate management accounting students in the United Kingdom, showed that the most significant benefits of using case studies were an awareness that there are several solutions to a problem and insights into the complexity of "real-world" business decisions. Boyce et al. (2001) point out that the most important benefit of the case study method is that theoretical issues are grounded in 
a practical context. This promotes an active learning approach with a higher level of understanding. Therefore, teaching ethical conduct principles, professionalism and pervasive skills can be accomplished through case study-based teaching (Fortin \& Legault, 2010).

Although researchers in general perceive the use of case studies in accounting education as efficient for pervasive skills development, these benefits are also questioned in the literature. For instance, Wolcott et al. (2002) challenge the findings of some researchers who argue that students' critical thinking skills are enhanced through teaching strategies such as case studies. They posit that researchers should examine empirically whether critical thinking skills are developed and achieving the desired effects (Wolcott et al., 2002).

Whilst the literature outlines the benefits of using case studies to enhance accounting students' pervasive skills (Ahmad \& Sulaiman, 2013; Ballantine \& McCourt Larres, 2004; Van der Merwe, 2013), most of these studies were conducted at residential universities. Brenner, Jeancola and Watkins (2015) suggest that mini-cases may be a solution in "time challenged" accounting courses. They explain that mini-cases are more efficient and effective than traditional, lengthy case studies, and thus allowance is made for flexibility in transferring various skills. In general, there is a belief that case studies could be used as a useful teaching method in the ODL environment (Wessels \& Binza, 2012). However, in the literature there is a paucity of studies on how case studies develop pervasive skills in the field of accounting in an ODL environment. Apostolou, Dorminey, Hassell and Rebele (2016) conducted a literature review of accounting education literature published in 2015, and although they found $\mathbf{2 0}$ cases, these were not presented in an ODL environment. The same authors also conducted a literature review of accounting education literature published in 2013 and 2014 and yet again, no mention was made of any cases in an ODL environment (Apostolou, Dorminey, Hassell, \& Rebele, 2015). The empirical research reported on in this article therefore focused on the use of case studies in an ODL institution.

\section{METHOD}

Apart from conducting an extensive literature review, an explorative qualitative approach was followed which, according to Henning, Van Rensburg and Smit (2004) provides an understanding of the phenomenon under study. Semi-structured, in-depth interviews were the primary instrument used. By conducting an interview, the prospect of offering rich data occurs (Newton, 2010). An interview is a controlled exchange of words effective for exploring people's opinions (Hofstee, 2006; Wiid \& Diggines, 2015).

\section{Participants}

A pilot interview was conducted with an ODL specialist, Professor Paul Prinsloo of Unisa. His insights, ideas and suggestions were valuable in designing the final interview schedule. In order to gain an understanding of their perception on the viability of introducing case studies or a case study-based module in an ODL Accounting environment, purposive sampling was used to conduct interviews with management members of the College of Accounting Sciences (CAS) who represent ODL academics. In 2015, 33069 students were enrolled in this college (Unisa, 2017c). A key advantage of purposive sampling is that it is planned and aimed at a targeted group of people (Tongco, 2007). Figure 1 below provides an overview of the structure of CAS at Unisa and indicates the management positions in the College. Eleven members of the CAS management were chosen because they could be regarded as the "voice of the academics" (Barac \& Du Plessis, 2014) representing the respective departments. Only members of management directly involved in the tuition portfolio were interviewed. Nobody in the management group was excluded based on race, age or gender. 


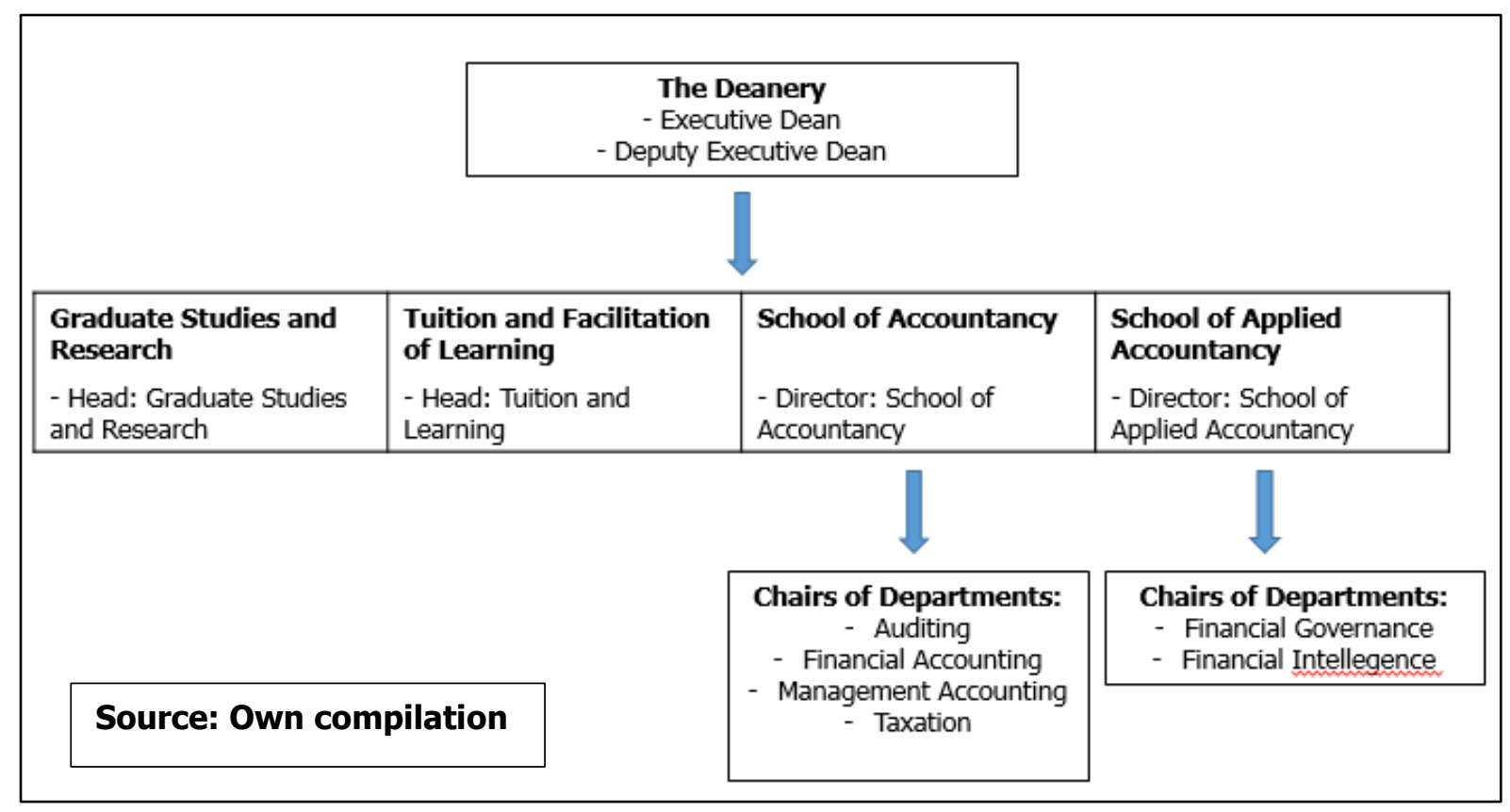

Figure 1. Structure of CAS, Unisa

Unisa was selected, since it is Africa's leading and largest ODL institution (Dhunpath \& Dhunpath, 2015; Letseka, 2015) attracting students from 130 countries in Africa and globally (Unisa, 2017c). Unisa is the furthermore the longest standing dedicated distance education university in the world, "enrolling nearly one-third of all South African students" (Unisa, 2017b) providing study opportunities to more than 400000 students from across South Africa, Africa and other parts of the world (Unisa, 2017a). Although Unisa is not the only distance learning institution in South Africa, it is the only distance education institution operating on a university level (Gerber, 2013). In addition, Unisa is accredited with SAICA and from the published APC 2014 results document available on SAICA's website, it is evident that Unisa delivers the largest number of students who pass their final test of competence examination (SAICA, 2015). Unisa is also accredited with CIMA, the largest management accounting body in the world (Unisa, 2015).

\section{Data Collection and Analysis}

The interview questions were clearly structured (Cohen, Manion \& Morrison, 2007) and trust was kept intact during the interviews by professionalism and showing respect for the participants (Newton, 2010). Ethical clearance for the study was obtained from the Ethics Review Committee of the College of Accounting Sciences (CAS) (ref no.: 2015_CAS_001) and permission for the study was granted by the Unisa Senate Research and Innovation Higher Degrees Committee (ref no.: 2015_RPSC_008).

The anonymity of the participants was guaranteed and they were informed that they could choose not to participate at any point during the interview. Participation in the study was voluntary and participants were invited to access the results of the study if they wished to do so. All of the interviews were conducted in English. The interviews were recorded with a digital voice recorder, transcribed and profiled. The transcription of the data remained strictly confidential and the data was analyzed through an inductive thematic analysis method.

Interviewees were asked whether they believed that there is a need for the introduction of a case study-based module (focusing on enhancing certain pervasive skills) with the purpose of delivering better prepared, practice-ready students. The interviewees were also asked whether ODL accounting educators within the respective departments have such a 
module in place, and whether they perceive such a module as beneficial to students as well as future employers of these students.

The results in this study were limited to the perceptions of the use of case studies in accounting education in one South African ODL institution, albeit the largest ODL institution in Africa. Therefore, the results of this study could inform accounting education in other distance learning institutions. Additionally, this study only focused on the conceptual frameworks of two professional accounting bodies actively involved in South African accounting and management accounting education, namely SAICA and CIMA. As in the study of Van der Merwe (2013), this study is based on the perceptions of participants, and does not contain empirical evidence of actual skills development.

Operational measures were applied to ensure trustworthiness. The primary researcher conducted the interviews (credibility). In-depth discussions were held and the results were contextualized in the literature (transferability). The researcher kept an audit trail of the study in case an auditor wished to verify the trustworthiness of the findings (conformability). The research process was clearly presented and all aspects of the study were described (dependability). No interviewees were excluded on the basis of race, age or gender (authenticity).

\section{FINDINGS}

In order to determine if accounting educators in an ODL institution perceive a need for the introduction of a case study module to enhance the pervasive skills of prospective accounting professionals, responses were interpreted according to the following themes that emerged during the interviews:

Unisa's Responsibility to Develop Accounting Graduates' Pervasive Skills

In accordance with the literature (De Lange et al., 2006; Dixon, Belnap, Albrecht, \& Lee, 2010; Gammie et al., 2002; Howieson, 2003), it was clear from the interviews that the respondents generally agreed that the work environment requires students to develop pervasive skills during their accounting studies.

All save one of the interviewees strongly felt that the university has a responsibility to develop graduates' pervasive skills. While one interviewee was skeptical about the ability of an ODL institution to actually assess pervasive skills, another said that "these skills are only obtained at the end of the graduates' practical training period". One interviewee clearly stated that students must be assessed for their "competencies to fit into practice". From the responses, it also became clear that the university should not only address the incorporation of pervasive skills because the professional bodies have changed their approach, but because it has a responsibility to turn out graduates with pervasive skills, especially critical thinking skills.

One interviewee posited that pervasive skills are not only needed by SAICA, CIMA and other professional bodies, but also by broader society - hence Unisa's responsibility to instill pervasive skills in all graduates, whether or not this is specifically required by professional bodies.

The Current Practices at Unisa Incorporating Case Studies in the Accounting Curriculum Although interviewees involved in teaching postgraduate modules responded that they did embed real-life scenarios in their study material, as well as formative and summative assessment practices, those involved at undergraduate level mostly stated that they did not really use case studies as part of their curriculum. This is mainly because they teach semester modules and the two-hour examinations do not allow for case studies, where a lot of reading time is required. With regard to the postgraduate CIMA modules, it was clearly stated that there is a strong emphasis on case studies. Three of the five postgraduate CIMA modules use one comprehensive case study that integrates all three modules' study material for summative assessment purposes. When compared to the case 
studies set by the professional bodies, one interviewee responded that specifically on the undergraduate level, case studies are far too limited to test pervasive skills. This is in line with another interviewee's opinion that the case studies in their postgraduate degree program are "not totally integrated because they only focus on one field".

The interviewees responded in a similar way to the question of whether case studies should be included in the current accounting curriculum and if so, should they be integrated into an existing module or rather developed as a separate module? Respondents mostly felt that case studies should be integrated into existing modules. This is consistent with the findings of Hassall et al. (2003), who support this view, as both CIMA employers and students were of the opinion that pervasive skills should be integrated throughout the accounting curriculum currently being taught at universities. However, one participant suggested that it should be a separate module in the final year of the postgraduate qualification, a module that will integrate the knowledge acquired in all the modules offered at that level. One interviewee shares the view of Krause (2005) whereby the integration of case studies in existing modules in order to ground the theory in practice is encouraged. Another reiterated that students need practical examples in order to better understand some of the topics.

The question of at which level case studies should be introduced to accounting students received a broad response from interviewees. While some felt that it should be introduced from first-year level, others strongly responded that it should only be introduced from third year or at the postgraduate level. One interviewee responded that because of, for instance, the deterioration of language and writing standards at high school level, case studies should be implemented as early as possible so that students can practice writing properly. According to some interviewees, at the third-year level students should at least be able to integrate knowledge and at postgraduate level they should "think outside the box" and be able to give advice based on the information given in the scenarios.

Challenges with the Implementation of Case Studies for Accounting Education in an ODL Environment

While some interviewees regarded the caliber and profile of ODL learners as making it difficult to incorporate case studies, others said that students who are already working will more easily relate to real-life scenarios and be able to incorporate the pervasive skills deemed necessary in the workplace. Some interviewees felt that apart from the full curriculum and lack of notional hours, the two-hour examinations pose a challenge for including case studies in the summative assessments and that it would also be difficult to mark comprehensive case studies in a short space of time due to the vast student numbers at Unisa. Some interviewees remarked that some Unisa students lack access to internet facilities to download case studies and upload answers. This is in line with the fact that internet connectivity and IT skills of ODL students in South Africa are a challenge (Kamanja, 2007).

One interviewee said that ODL students feel isolated and do not have contact sessions and discussions with lecturers or fellow students. Tucker (2012) also found that distance learners often feel isolated and deprived of peer-to-peer learning that takes place more easily in contact-based learning environments. Another interviewee mentioned that it is difficult in an ODL environment to do case studies as part of group work. Some interviewees said that an ODL institution did not face specific challenges regarding the implementation of case studies, while one interviewee even said that they could be a solution for nonvenue-based assessments.

\section{Benefits of Teaching Accounting Case Studies in ODL Institutions}

One interviewee stated that good content and level-appropriate case studies can be "very rich to also teach pervasive skills". Since many of the ODL students already work, exposure to case studies will not only prepare them for the professional examinations they have to write, but also improve their performance in the workplace. Another interviewee remarked that case studies would improve students' higher thinking or critical thinking skills and teach them to reflect on and integrate information in order to take better decisions. As 
mentioned by one participant, ODL students already work independently and working on case studies can strengthen that independence and enhance their problem-solving skills. It was also mentioned that the written communication skills of ODL students would be enriched by case studies.

Case studies were perceived by the interviewees to enrich various pervasive skills of ODL students such as communication, critical thinking, problem-solving, decision-making and thinking independently and on their feet. However, one interviewee mentioned that students often do not understand the basics of business, while another mentioned that case studies do not always teach integration of different disciplines. Overall, however, they felt that the inclusion of more case studies in the current accounting curriculum would better prepare ODL students for the professional examinations to be written and for the working environment.

\section{DISCUSSIONS AND CONCLUSION}

The literature clearly showed that the work environment requires pervasive skills that accounting graduates should, but do not always, have. The challenge of reform in accounting education is therefore to enhance teaching techniques to also include pervasive skills development. From the interviews it can be deduced that the ODL accounting lecturers perceive a case study-based approach to be effective in developing the pervasive skills of accounting graduates. They agreed that tertiary institutions, including ODL institutions, have a responsibility to develop accounting graduates' pervasive skills and equip them to be practice-ready. Case studies should increasingly be incorporated throughout the undergraduate and postgraduate accounting curriculum, focusing on honing the pervasive skills required of accounting graduates.

Case studies should assist students to better understand certain topics by putting theory into practice. Case studies should be included in existing study material, formative and summative assessments. A staggered implementation approach of case studies, tailored for different difficulty levels would be suitable for pervasive skills enhancement.

In the ODL environment, some institutions might find large student numbers challenging, because it is difficult to assess students by means of case studies when there is limited time for grading tests and examinations. Other challenges that ODL institutions should consider include: the readiness of faculties and the capacity of lecturers to develop more case studies; the curriculum; a possible lack of notional hours; the structure of examinations; the geographical spread of their students; the profile, caliber and diverse backgrounds of their students; the authenticity of the work their students submit; a possible lack of skills; and internet connectivity.

In contrast to residential universities, group work is more challenging in an ODL environment because of the vast geographical spread of students and the fact that many distance learners have limited internet connectivity. However, if case studies could be assigned to ODL students in a group context, this could facilitate peer learning and increase motivation. An "educational blog" or online discussion forum can be used by distance education institutions whereby students can engage with each other on an online platform that can be monitored by the educator. This will promote socialization; create an atmosphere of online community whilst developing important pervasive skills of the students, such as communication skills. Distance education institutions should seek more opportunities for students to collaboratively interact with other students and educators.

It is therefore recommended that the training of accounting students should be adapted to include pervasive skills training through case studies. Case studies should increasingly be incorporated into the study material. In an ODL environment, case study discussions should provide an opportunity for students to do self-assessment, allowing for the improvement of their interpersonal and self-directional skills and also to participate in online group discussions, allowing for the improvement of their communication skills. A set of online 
model answers could assist students to identify their possible lack of comprehension and how to modify their learning strategies. Case studies based on real-life scenarios can potentially increase student's analytical, critical thinking and judgement skills. Incorporating case study group assignments in an ODL environment can furthermore also cater for students' need for peer learning.

Suggested directions for further research are:

$>$ ODL institutions should conduct research in order to understand their students' perception of the need to introduce more case studies or a case study-based module to develop their pervasive skills.

> Future research could potentially investigate actual skills improvement experienced by ODL students because of case studies.

\section{BIODATA and CONTACT ADDRESSES of AUTHORS}

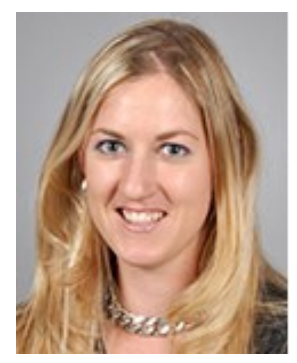

Yolande REYNEKE, has been a member of the South African Institution of Chartered Accountants (SAICA) since 2011. In 2013 she received an Excellence in Tuition award within the College of Economic and Management Sciences at the University of South Africa (Unisa). She received her Master of Philosophy (with specialization in Accounting Sciences) in 2016 through Unisa. She is currently a Senior Lecturer at Unisa working in the Department of Management Accounting within the College of Accounting Sciences. Her research interest areas are e-learning, distance education and accounting education.

\section{Yolande REYNEKE}

Department of Management Accounting, College of Accounting Sciences University of South Africa, 0003, Pretoria, South Africa

Phone: +27124294046

E-mail: reyney@unisa.ac.za

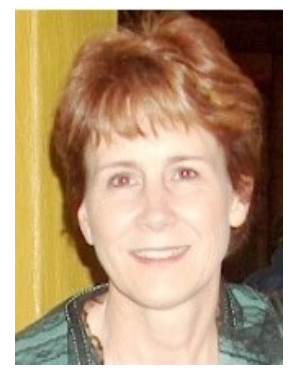

Christina Cornelia SHUTTLEWORTH is the Head: Graduate Studies and Research, in the College of Accounting Sciences at Unisa. She is an associate professor in Management Accounting. She has more than 21 years' experience in tertiary education. She has authored various articles published in subject-related and accredited journals. Her research interests include quality management systems (QMS), financial literacy, accounting education and the teaching of pervasive skills in an open distance e-learning environment.

\section{Cornelia Christina SHUTTLEWORTH}

Graduate Studies and Research, College of Accounting Sciences

University of South Africa, 0003, Pretoria, South Africa

Phone: +27 124294763

E-mail: shuttcc@unisa.ac.za

\section{REFERENCES}

Ahmad, N.N.N., \& Sulaiman, M. (2013). Case studies in a passive learning environment: some Malaysian evidence. Accounting Research Journal, 26(3),173-196.

Albrecht, W.S., \& Sack, R.J. (2000). Accounting education: Charting the course through a perilous future. Chapter 1: Why accounting education may not survive in the future. Accounting Education Series, 16, 1-72. Sarasota, USA: American Accounting Association. 
American Accounting Association (AAA). (1986). Committee on the future structure, content, and scope of accounting education (The Bedford Committee). SPECIAL REPORT: Future accounting education: Preparing for the expanding profession. Issues in Accounting Education, Spring edition, 1(1), 168-195.

Apostolou, B., Dorminey, J.W., Hassell, J.M., \& Rebele, J.E.(2015). Accounting education literature review (2013-2014). Journal of Accounting Education, 33(1), 69-127.

Apostolou, B., Dorminey, J.W., Hassell, J.M., \& Rebele, J.E. (2016). Accounting education literature review (2015). Journal of Accounting Education, 35(1), 20-55.

Arquero Montano, J.L., Cardoso, S.M.J., \& Joyce, J. (2004). Skills development, motivation and learning in financial statement analysis: An evaluation of alternative types of case studies. Accounting Education: An International Journal, 13(2), 191-212.

Ballantine, J.A., \& McCourt Larres, P.M.C. (2004). A critical analysis of students' perceptions of the usefulness of the case study method in an advanced management accounting module: The impact of relevant work experience. Accounting Education: An International Journal, 13(2), 171-189.

Barac, K. (2009). South African training officers' perceptions of the knowledge and skills requirements of entry-level trainee accountants. Meditari Accountancy Research, 17(2),19-46.

Barac, K., \& Du Plessis, L. (2014). Teaching pervasive skills to South African accounting students. Southern African Business Review, 18(1), 53-79.

Bezuidenhout, A. (2013). The changing role of the ODL academic: An auto-ethnographical account. Progressio, 35(2), 19-33.

Boyce, G. (2004). Critical accounting education: Teaching and learning outside the circle. Critical Perspectives on Accounting, 15, 565-586.

Boyce, G., Williams, S., Kelly, A., \& Yee, H. (2001). Fostering deep and elaborative learning and generic (soft) skill development: The strategic use of case studies in accounting education. Accounting Education: An International Journal, 10(1), 37-60.

Bozok, M.S. (2011). The effects of distance education materials on the traditional accounting course. Turkish Online Journal of Distance Education. 12(2), 1-4.

Brenner, V. C., Jeancola, M. M., \& Watkins, A. L. (2015). Using mini-cases to develop AICPA core competencies. Advances in Accounting Education: Teaching and Curriculum Innovations, 16(1), 21-44.

Brooke, S.L. (2006). Using the case method to teach online classes: Promoting Socratic dialogue and critical thinking skills. International Journal of Teaching and Learning in Higher Education, 18(2), 142-149.

Bui, B., \& Porter, B. (2010). The expectation-performance gap in accounting education: An exploratory study. Accounting Education: An International Journal, 19(1-2), 23-50.

Burns, J., \& Baldvinsdottir, G. (2005). An institutional perspective of accountants' new roles the interplay of contradictions and praxis. European Accounting Review, 14(4), 725757.

Chu, L., \& Libby, T. 2010. Writing mini-cases: an active learning assignment. Issues in Accounting Education, 25(2): 245-265.

CIMA vide Chartered Institute of Management Accountants. (2012). Essential skills for T4 success - CIMA. Retrieved from http: / /www.cimaglobal.com/Documents/ Student\%20docs/2010\%20curriculum\%20docs/T4/T4_dramaintoacrisis_updatedFe b2012.pdf [Accessed 14/08/2013]

CIMA vide Chartered Institute of Management Accountants. (2014). 2015 Professional Qualification Syllabus. Retrieved from http://www.cimaglobal.com/2015-syllabus/ [Accessed 03/03/2014]. 
Coetzee, S., \& Oberholzer, R. (2009). The tax knowledge of South African trainee accountants: A survey of the perceptions of training officers in public practice. Accounting Education: An international Journal, 18(4), 421-441.

Cohen, L., Manion, L., \& Morrison, K. (2007). Research methods in education. 6th edition. London: Routledge Falmer.

Cooper D.J., Everett J., \& Neu, D. (2005). Financial scandals, accounting change and the role of accounting academics: A perspective from North America. European Accounting Review, 14(2), 373-382.

Cranmer, S. (2006). Enhancing graduate employability: Best intentions and mixed outcomes. Studies in Higher Education, 31(2), 169-184.

Cullen, J., Richardson S., \& O'Brian, R. (2004). Exploring the teaching potential of empiricallybased case studies. Accounting Education: An International Journal, 13(2), 251-266.

Davis, C., \& Wilcock, E. (2003). Teaching materials using case studies. Guides for Lecturers. UK Centre for Materials Education, University of Liverpool, England. Retrieved from www.materials.ac.uk/guides/casestudies.asp [Accessed 18/01/2016].

De Lange, P., Jackling, B., \& Gut, A. (2006). Accounting graduates' perceptions of skills emphasis in undergraduate courses: An investigation from two Victorian universities. Accounting and Finance, 46(3), 365-386.

De Villiers, R. (2010). The incorporation of soft skills into accounting curricula: Preparing accounting graduates for their unpredictable futures. Meditari Accountancy Research, 18(2), 1-22.

Dhunpath, S., \& Dhunpath, R. (2015). Student support for Open Distance Learning (ODL). In: $M$ Letseka (ed). Open distance learning (ODL) in South Africa. EBSCO Publishing: eBook Collection (EBSCOhost). Hauppauge, NY: Nova Science:105-116.

Diller-Haas, A. (2004). Time to change introductory accounting. Retrieved from http://www.nysscpa.org/cpajournal/2004/404/essentials/p60.htm [Accessed $16 / 02 / 2014]$

Dixon, J., Belnap, C., Albrecht, C., \& Lee, K. (2010). The importance of soft skills. Corporate Finance Review, 14(6), 35-38.

Donovan, C. (2005). The benefits of academic/practitioner collaboration. Accounting Education: An International Journal, 14(4), 445-452.

Dzakiria, H. (2012). Illuminating the importance of learning interaction to Open Distance Learning (ODL) success: A qualitative perspectives of adult learners in Perlis, Malaysia. European Journal of Open, Distance and eLearning, 2012(2). Retrieved from http://www.eurodl.org/materials/contrib/2012/Dzakiria.pdf [Accessed 21/03/2015]

Fortin, A., \& Legault, M. (2010). Development of generic competencies: Impact of a mixed teaching approach on students' perceptions. Accounting Education: An International Journal, 19(1-2), 93-122.

Fouche, J.P. (2013). A renewed call for change in accounting education practices. International Journal of Educational Sciences, 5(2), 137-150.

Gammie, B., Gammie, E., \& Cargill, E. (2002). Personal skills development in the accounting curriculum. Accounting Education: An International Journal, 11(1), 63-78.

Geduld, B. (2013). Students' experiences of demands and challenges in open distance education: A South African case. Progressio, 35(2), 102-125.

Gerber, L. (2013). Is Unisa the only distance learning option in South Africa? Retrieved from https:// www.careersportal.co.za/universities/universities/1316-is-unisa-the-onlydistance-learning-option-in-south-africa.html [Accessed 28/09/2017].

Goretzki, L., Strauss, E., \& Weber, J. (2013). An institutional perspective on the changes in management accountants' professional role. Management Accounting Research, 24(1), 41-63. 
Hassall, T., Joyce, J., Arquero Montano, J.L., \& Donoso Anes, J.A. (2003). The vocational skills gap for management accountants: The stakeholders' perspectives. Innovations in Education and Teaching International, 40(1), 78-88.

Hassall, T., Joyce, J., Arquero Montano, J.L., \& Donoso Anes, J.A. (2005). Priorities for the development of vocational skills in management accountants: A European perspective. Accounting Forum, 29(4), 379-394.

Hassall, T., \& Milne, M.J. (Guest Editors). (2004). Using case studies in accounting education. Accounting Education: An International Journal, 13(2), 135-138.

Henning, E., Van Rensburg, W., \& Smit, B. (2004). Finding your way in qualitative research. Pretoria: Van Schaik.

Heydenrych, J.F., \& Prinsloo, P. (2010). Revisiting the five generations of distance education: Quo vadis? Progressio, 32(1), 5-26.

Hofstee, E. (2006). Constructing a good dissertation. Sandton: Interpak Books.

Howieson, B. (2003). Accounting practice in the new millennium: is accounting education ready to meet the challenge? The British Accounting Review, 35(2), 69-103.

Howieson, B., Hancock, P., Segal, N., Kavanagh, M., Tempone, I., \& Kent, J. (2014). Who should teach what? Australian perceptions of the roles of universities and practice in the education of professional accountants. Journal of Accounting Education, 32(3), 259-275.

Jackling, B., \& De Lange, P. (2009). Do accounting graduates' skills meet the expectations of employers? A matter of convergence or divergence. Accounting Education: An international Journal, 18(4), 369-385.

Järvenpää, M. (2007). Making business partners: A case study on how management accounting culture was changed. European Accounting Review, 16(1), 99-142.

Kamanja, L.G. (2007). ICTs promises and pitfalls in open and distance learning. South African Journal of Higher Education, 21(6), 721-731.

Kashora, T, Van der Poll, H.M., \& Van der Poll, J.A. (2016). E-learning and technologies for open distance learning in Management Accounting. Africa Education Review, 13(1), 1-19.

Kavanagh, M.H., \& Drennan, L. (2008). What skills and attributes does an accounting graduate need? Evidence from student perceptions and employer expectations. Accounting and Finance, 48, 279-300.

Keevy, M. (2013). An analysis of accounting academic's awareness of, and ability to deliver, pervasive qualities and skills. Athens: ATINER's conference paper series, No: BUS2013-0458.

Kimmel, P. (1995). A framework for incorporating critical thinking into accounting education. Journal of Accounting Education, 13(3), 299-318.

Krause, M. J. (2005). Bridging the gap between professors and practitioners: Quasi-case studies. CPA Journal, 75(11), 68-69.

Letseka, M. (2015). Introduction: Open Distance Learning (ODL) in South Africa. In: M Letseka (ed). Open distance learning (ODL) in South Africa. EBSCO Publishing: eBook Collection (EBSCOhost). Hauppauge, NY: Nova Science:1-6.

Lucas, U., Cox, P., Croudace, C., \& Milford, P. (2004). Who writes this stuff?: Students' perceptions of their skills development. Teaching in Higher Education, 9(1), 55-68.

Martin, R. (2007). Online education and training: Well-founded pedagogy or state corporate interests? South African Journal of Higher Education, 21(3), 473-484.

Mbatha, B. (2015). A paradigm shift: Adoption of disruptive learning innovations in an ODL environment: The case of the University of South Africa, International Review of Research in Open and Distributed Learning, 16(3), 218-232. 
McLoughlin, C., \& Marshall, L. (2000). Scaffolding: A model for learner support in an online teaching environment. In Hermann, A., \& Kulski, M.M. (eds). Flexible futures in tertiary teaching. Proceedings of the $9^{\text {th }}$ Annual teaching and learning forum 2000. Perth, Curtin University of Technology. Retrieved from http: / / www.c3l.unioldenburg.de/cde/support/readings/loughlin2.html [Accessed 21/03/2015]

Mohamed, E.K., \& Lashine, S.H. (2003). Accounting knowledge and skills and the challenges of a global business environment. Managerial Finance, 29(7), 3-16.

Morris, M., Burnett, R.D., Skousen, C., \& Akaaboune, 0. 2015. Accounting education and reform: a focus on pedagogical intervention and its long-term effects. The Accounting Educators' Journal, XXV: 67-93.

Newton, N. (2010). Exploring qualitative methods. Retrieved from http: / / www.academia.edu/1561689/The_use_of_semistructured_interviews_in _qualitative_research_strenghts_and_weaknesses [Accessed 20/01/2015].

Nti, K. (2015). Supporting access to open online courses for learners of developing countries. International Review of Research in Open and Distributed Learning, 16(4), 156-171.

Oliver, M. (2012). Prospective changes of the Part II Qualifying examination. SAICA presentation by the Senior Executive: Professional Development held at Unisa.

Palmer, K.N., Ziegenfuss, D.E., \& Pinsker, R.E. (2004). International knowledge, skills, and abilities of auditors/accountants: Evidence from a recent competency study. Managerial Auditing Journal, 19(7), 889-896.

Penn, M.L., Currie, C.S.M., Hoad, K.A., \& O'Brien, F.A. 2016. The use of case studies in OR teaching. Higher Education Pedagogies, 1(1),16-25.

Rebele, J. E., \& St. Pierre, E. K. (2015). Stagnation in accounting education research. Journal of Accounting Education, 16(1), 1-51.

Ryan, P. (2008). A small experiment in online learning. South African Journal of Higher Education, 22(4), 877-888.

Sad, S.N., Goktas, O., \& Bayrak, I. (2014). A comparison of student views on web-based and face-to-face higher education. Turkish Online Journal of Distance Education, 15(2), 209-226.

SAICA, vide South African Institute of Chartered Accountants. (2010). Competency framework: Detailed guidance for academic programmes. Johannesburg: SAICA.

SAICA, vide South African Institute of Chartered Accountants. (2013). Changes to Part II Exam 2014 - APC. Retrieved from https: / / www.saica.co.za/LearnersStudents/Examinations/ChangestoPartIIexam 2014/APC/ [Accessed 24/12/2013]

SAICA, vide South African Institute of Chartered Accountants. (2015). APC November 2014 results. Retrieved from https:// www.saica.co.za/Portals/0/LearnersStudents/Examinations/Part_II_APC_2 014_StatisticsOfResults.pdf [Accessed 23/03/2015].

Shuttleworth, C.C. 2012. Setting the employability skills agenda for accounting graduates in an ODL environment. In: M Coetzee, J Botha, N Eccles, $\mathbf{H}$ Nienaber, \& $\mathbf{N}$ Holtzhausen (eds). Developing student graduateness and employability: issues, provocations, theory and practical guidelines. Randburg: 243-261.

Siegel, G., \& Sorensen, J.E. (1999). Counting more counting less: Transformations in the management accounting profession. Montvale, NJ: Institute of Management Accountants.

Sorensen, J.E. (2009). Management accountants in the United States: practitioner and academic views of recent developments. In: Chapman, CS., Hopwood, AG., \& Shields, MD (Eds), Handbook of Management Accounting research. Amsterdam: Elsevier pp. 1271-1296. 
Stainbank, L.J. (2010). Students' perceptions of the usefulness of an accounting project in acquiring accounting knowledge and professional skills. South African Journal of Accounting Research, 24(1), 79-100.

Stout, D.E. (1996). Experiential evidence and recommendations regarding case-based teaching in undergraduate cost accounting. Journal of Accounting Education, 14(3), 293-317.

Strauss-Keevy, M., \& Mare, D. (2015). Influence: The development of pervasive skills 1 April 2015. Retrieved from http://www.accountancysa.org.za/influence-the-developmentof-pervasive-skills/ [Accessed 15/01/2016]

Tongco, M.D. (2007). Purposive sampling as a tool for informant selection. Ethobotany Research \& Applications, 5, 147-158.

Tucker, S.Y. (2012). Promoting socialization in distance education. Turkish Online Journal of Distance Education. 13(1), 174-182.

Tucker, S.Y. (2014). Transforming pedagogies: Integrating $21^{\text {st }}$ Century Skills and Web 2.0 Technology. Turkish Online Journal of Distance Education. 15(1), 166-173.

Unisa, vide University of South Africa. (2017a). Facts and figures. Retrieved from http://www.unisa.ac.za/sites/corporate/default/About/Facts-\&-figures [Accessed 28/09/2017]

Unisa, vide University of South Africa. (2017b). The leading ODL university. Retrieved from http://www.unisa.ac.za/sites/corporate/default/About/The-leading-ODL-university [Accessed 28/09/2017]

Unisa, vide University of South Africa. (2017c). Student enrolments. Retrieved from http:// www.unisa.ac.za/sites/corporate/default/About/Facts-\&-figures/Studentenrolments [Accessed 28/09/2017].

Unisa, vide University of South Africa. (2015). Management Accounting: CIMA accreditation. Retrieved from http: // www.unisa.ac.za/default.asp?Cmd=ViewContent\&ContentID= 24889 [Accessed 23/03/2015].

Vakoufari, M., Christina, A., \& Mavroidis, I. (2014). Self-esteem and loneliness as factors affecting distance learning students. European Journal of Open, Distance and eLearning, 17(2), 99-115.

Van der Merwe, N. (2013). An evaluation of an integrated case study and business simulation to develop professional skills in South African accountancy students. International Business \& Economics Research Journal, 12(10), 1137-1156.

Van Romburgh, H., \& Van der Merwe, N. (2015). University vs practice. A pilot study to identify skills shortages that exist in first-year trainee accountants in South Africa. Industry \& Higher Education, 29(2):141-149.

Weil S., Oyelere P., Yeoh, J., \& Firer, C. (2001). A study of students' perceptions of the usefulness of case studies for the development of finance and accounting-related skills and knowledge. Accounting Education: An International Journal, 10(2), 123146.

Wessels, P.L. (2008). The identification and discussion of strategies for implementing an IT skills framework in the education of professional accountants. South African Journal of Accounting Research, 22(1), 147-182.

Wessels, R.G., \& Binza, M.S. (2012). A longitudinal study on teaching case studies in Public Administration at an Open Distance Learning university. In: Coetzee, M., Botha J., Eccles N., Nienaber, H., \& Holtzhausen, N. (Eds). Developing student graduateness and employability - Issues, provocations, theory and practical guidelines. Randburg: Knowres Publishing pp. 477-491.

Wiid, J., \& Diggines, C. (2015). Marketing research. 3rd edition. Cape Town: Juta.

Wilton, N. (2008). Business graduates and management jobs: An employability match made in heaven? Journal of Education and Work, 21(2), 143-158. 
Wolcott, S.K., Baril, C.P., Cunningham, B.M., Fordham, D.R., \& St Pierre, K. (2002). Critical thought on critical thinking research. Journal of Accounting Education, 20, 85-103.

Woronoff, M.A. (2009). What law schools should teach future transactional lawyers: perspectives from practice. Retrieved from https://dx.doi.org/10.2139/ssrn.1430087 [Accessed 16/02/2014].

Zraa, W., Kavanagh, M., \& Hartle, R.T. (2011). Teaching accounting in the new millennium. Paper presented at the Cambridge Business and Economics Conference. Retrieved from www.facultyforum.com/cbec/2011CBECProceedings [Accessed 22/07/2014]. 